\title{
Effect of Three Plant Extracts on Egg Hatchability and Larval Development of Culex pipiens $\mathrm{L}$.
}

\author{
Ahmed. A. Bakhashwain and Ahmed. A. Zaitoun ${ }^{1}$
}

\begin{abstract}
The activity of methanolic plant extracts from Rhazya stricta Cleome paradoxa and Heliotrobium bacciferum has been investigated towards larval mortality and development of Culex pipiens L. Plant extracts exhibited variable biological activity. The greatest activity was observed for $R$ stricta which showed LC 50s of 154.2 and 84.2 ppm, respectively after 2 and 10 days of exposure. Percentage of larval mortality was $95.33 \%$ in the treatment with extracts of $R$ stricta and $84.8 \%$ in C. paradoxa. Egg hatchability was significantly reduced in $R$ stricta concentrations. All concentrations of the plant extracts from $R$ stricta, C. paradoxa $(200 \mathrm{ppm}$ and above) and $\boldsymbol{H}$. bacciferum (400ppm and above) caused significantly high hindrance to the subsequent larval development and reduced both pupation and adult emergence. Drastic retardation of development was shown by $R$ stricta extracts, where only $19.3 \%$ and $9 \%$ of the larval managed to reach pupal and adult stages, respectively, when reared in very low concentration $(100 \mathrm{ppm})$ of the extract. However, C.paradoxa and $H$. bacciferum were more effective at higher concentrations. Application of such plant extracts to mosquito breeding sites may have great practical importance in relation to non-synthetic chemical control of these serious disease vectors.
\end{abstract}

\section{INTRODUCTION}

Insect -transmitted diseases remain a major source of illness and death worldwide. Mosquitoes alone transmit diseases to more than 700 million people annually (Taubes 1997). These diseases including malaria, filariasis, yellow fever, dengue and Japanese encephalitis, contribute significantly to poverty and social debility in tropical countries (Jang, et al., 2002 and Rajkumar and Jebanesan 2005). Control of such diseases is becoming increasingly difficult because the over production of detoxifying mechanisms of chemical insecticides has reported for Culex species (Severini, et al., 1993).On the other hand, majority of mosquito species have developed high levels of resistance to microbial control agents (Rao, et al., (1995). One alternative approach is the use of natural products from plant origin ( Elhag, et al., 1996). The botanical insecticides are generally pest specific and are relatively harmless to the non-target organisms including human beings. They are also biodegradable and harmless to environment. The phytochemicals derived plant resourses can act as larvicides, insect growth regulators, repellent and ovipositional attractant (Das et, al., 2003 and Venkatachalam and Jebanesan, 2001). One plant species may possess substances with a wide range of activities, like extracts from Azadriachta indica which showed antifeedent, antioviposition, repellent and growth- regulating activity (Schmutterrer, 1995). Insecticidal activity of many plants against several insect pests has been demonstrated (Carlini and Grossi-de-Sa, 2002, Kundu, et al., 2007, Boussada, et al., 2008 and Bakhashwain and Zaitoun 2009). The three plants of Heliotrobium bacciferum, Rhazya stricta and Cleome paradoxa are available in Saudi Arabia and used in folk medicine (Migahid, 1978).

In this study the effects of Methanolic extracts of aerial parts from three plant species: $H$. bacciferum, $R$. stricta and C. paradoxa aerial parts, on egg hatchability and larval development of Culex pipiens mosquitoes, have been investigated.

\section{MATERIALS AND METHODS}

Insects: A Culex pipiens L. (Diptera: Culicidae) colony maintained in the laboratory for more than 10 years was used. Mosquitoes were held at $27 \pm 1{ }^{\circ} \mathrm{C}, 70 \pm 5 \% \mathrm{RH}$, and a photo regime of 14:10 (light:dark) hr. Adults were provided with a $10 \%$ sucrose solution as food source. A pigeon was introduced twice a week to the adults for blood feeding. Larvae were reared in dechlorinated water under the same temperature and light conditions and were fed daily with baby fish food. The experiment was carried out at the Faculty of Meteorology, Environment and Arid land Agriculture, King AbdulAziz University, Jeddah, Saudi Arabia..

Plant extracts: Plant materials of Heliotrobium bacciferum, Rhazya stricta and Cleome paradoxa were collected from different parts in Saudi Arabia. $H$. bacciferum, C. paradoxa and $R$. stricta leaves were airdried for 48 hours, ground to fine parts and extracted with methanol at ambient temperature. A gentle warming to $35-40^{\circ} \mathrm{C}$ was sometimes found necessary. The mixture was stirred for $30 \mathrm{~min}$. by magnetic stirrer and left 24 hours. Then, it was condensed in a rotary vacuum evaporator of solvent in a water bath at $55^{\circ} \mathrm{C}$ according to Chitra, et al. (1993).

\footnotetext{
${ }^{1}$ King AbduAziz University, Faculty of Metrology, Environment and Arid Land Agriculture, Jeddah, Saudi Arabia

Received November 13, 2010, Accepted January 18, 2011
} 
Test procedure: Stock solutions of the three plant methanolic extracts were prepared by dissolving the extracted in warm distilled water (at $0.5 \mathrm{~g} / 100 \mathrm{ml}$ water). Different concentrations of 100, 200, 300, 400 and 500 ppm were prepared from stock solution. Freshly laid egg mass (about twenty eggs) or ten second instars larvae were transferred from the culture into plastic cups ( $8 \mathrm{~cm}$ diameter, $10 \mathrm{~cm}$ deep), each containing $30 \mathrm{ml}$ of desired concentration. Treatments were triplicate and control had only distilled water. Larvae were fed ad libitum and kept under laboratory conditions. Egg hatchability was determined at 4 and 7 days after treatment. Larval mortalities were counted at 2, 4 and 10 days after treatment. Percentage of successful pupation and adult emergence were determined by monitoring on daily basis until all adults in the control have emerged.

Data were analyzed using maximum likelihood procedures and values of LC50 were calculated according to Finney (1971). Data were corrected for control mortality (Abbott, 1925). Data of egg hatchability were analyzed by analysis of variance. If significant differences $(\mathrm{p}<0.05)$ occurred, means were separated by Duncan's multiple range test.

\section{RESULTS AND DISCUSSIONS}

The mortality (\%) of $C$. pipiens larvae treated with three plant extracts in methanol and their LC50 values and 95\%confidence limits at 2, 4 and 10 days after treatment are shown in Tables 1 and 2. Data showed that 95.3 and $84.8 \%$ mortality of larvae reached after
10 days of exposure to $500 \mathrm{ppm} R$. stricta and $C$. paradoxa extracts, respectively. However, the lowest $R$. stricta concentration (100ppm) caused $45 \%$ mortality after 2 days of treatment. $H$. bassifirum extracts caused the lowest mortalities, wherase highest concentration (500ppm) caused $71.7 \%$ mortality after 10 days of treatment. LC50s and 95\% confidence limits (CL) for each plant are given in Table 2. Data showed a significant differences. LC50 for second instar larvae were (154.2 and 84.2); 433.9 and 132.1) and (> 500 and 311.3 ) for $R$. stricta, $C$. paradoxa and $H$. bassifirum, respectively after 2 and 10 days from exposure. $R$. stricta was significantly more toxic at all exposure times than $C$ paradoxa and $H$. bassifirum.

Egg hatchablity was significantly lower $(\mathrm{p}<0.05)$ in all extracts than control (Table 3). At $100 \mathrm{ppm}$ concentration, $R$. stricta had the most severe effect on egg hatching rate which was reduced by about $31 \%$ compared with $C$. paradoxa and H. bassifirum. At their highest concentration (500 ppm), the three plant extracts reduced egg hatchability by about 83,57 and $36 \%$, for R. stricta, C. paradoxa and H. bassifirum, respectively. The effect of the three plant materials on growth and development of $C$. pipiens, larvae to adulthood are given in Table 4. There were considerable reduction in the percentage of larvae undergoing successful pupation in all treatments compared with control. No further larval development took place beyond the second instar in the $R$. stricta $500 \mathrm{ppm}$ concentration.

Table 1. Mortality percentage of $2^{\text {nd }}$ larvae of Culex pipiens larvae in media containing methanolic plant extracts at different exposure periods (2, 4 and 10 days)

\begin{tabular}{lcccc}
\hline Plant Extract & $\begin{array}{c}\text { Conc. } \\
\text { (ppm) }\end{array}$ & 2d & Mortality $(\%)$ & 4d \\
\hline Rhazya stricta & 100 & 45.00 & 50.00 & 59.33 \\
& 200 & 53.31 & 60.00 & 75.00 \\
& 300 & 56.72 & 66.76 & 78.76 \\
& 400 & 64.31 & 76.00 & 90.00 \\
Cleome paradoxa & 500 & 76.76 & 83.31 & 95.33 \\
& Cont. & 00.00 & 00.00 & 03.33 \\
\hline Heliotrobium bacciferum & 100 & 22.6 & 35.9 & 43.10 \\
& 200 & 27.8 & 42.6 & 61.00 \\
& 300 & 32.2 & 61.00 & 70.7 \\
& 400 & 48.2 & 68.6 & 76.7 \\
& 500 & 61.00 & 73.3 & 84.8 \\
& Cont. & 00.00 & 6.7 & 00.00 \\
\hline 100 & 8.20 & 17.3 & 27.8 \\
& 200 & 9.80 & 18.6 & 32.2 \\
& 300 & 12.5 & 26.3 & 42.60 \\
& 400 & 13.8 & 35.9 & 61.00 \\
\hline
\end{tabular}


Table 2. $\mathrm{LC}_{50}$ values and $95 \%$ confidence limits of $2^{\text {nd }}$ instar larvae of Culex pipiens larvae in media containing methanolic plant extracts

\begin{tabular}{lccc}
\hline Plant Extract & $\begin{array}{c}\text { Assay Time } \\
\text { (days) }\end{array}$ & Slope & LC50 (95\% CL) \\
\hline Rhazya stricta & 2 & 1.1 & $154.2(110.8-214.1)$ \\
& 4 & 1.3 & $113.2(79.5-160.7)$ \\
\hline Cleome paradoxa & 10 & 1.8 & $84.3(60.3-117.7)$ \\
& 2 & 1.4 & $433.9(95.4-2004.4)$ \\
Heliotrobium bacciferum & 4 & 1.6 & $232.8(194.7-278.1)$ \\
& 10 & 1.6 & $>52.1(103.3-168.9)$ \\
\hline
\end{tabular}

Table 3. Egg hatchability percentage of Culex in media containing ethanolic plant extracts

\begin{tabular}{lcc}
\hline Plant extract & Conc. $(\mathrm{ppm})$ & Egg hatchability $(\%)^{*}$ \\
\hline Rhazya stricta & 100 & $69.2 \mathrm{~cd}$ \\
& 200 & $58.0 \mathrm{de}$ \\
& 300 & $49.3 \mathrm{ef}$ \\
& 400 & $30.5 \mathrm{~g}$ \\
Cleome paradoxa & 500 & $17.4 \mathrm{~h}$ \\
& Control & $98.0 \mathrm{a}$ \\
\hline Heliotrobium bacciferum & 100 & $81.7 \mathrm{bc}$ \\
& 200 & $75.5 \mathrm{c}$ \\
& 300 & $67.6 \mathrm{~cd}$ \\
& 400 & $50.0 \mathrm{ef}$ \\
& 500 & $43.6 \mathrm{ef}$ \\
& Control & $98.2 \mathrm{a}$ \\
\hline & 100 & $86.7 \mathrm{~b}$ \\
& 200 & $81.7 \mathrm{bc}$ \\
& 300 & $75.5 \mathrm{~cd}$ \\
& 400 & $69.3 \mathrm{~cd}$ \\
& 500 & $63.0 \mathrm{~d}$ \\
\hline
\end{tabular}

*Means followed by the same letter are not significantly different at 5\% level, Duncan multiple test.

On the other hand all plant extracts had an evident inhibitory effect even at their lowest concentrations (100 $\mathrm{ppm}$ ), where the successful pupation were only 19.3, 39.3 and 68.1 for $R$. stricta, C. paradoxa and $\mathrm{H}$. bassifirum, respectively. Complete suppression of adult emergence was evident in the $500 \mathrm{ppm}$ concentration of $R$. stricta and $C$. paradoxa. The adult emerging percentages from the $100 \mathrm{ppm}$ treatments were 9.0, 14.9 and $39.0 \%$ for $R$. stricta, C. paradoxa and $\mathrm{H}$. bassifirum, respectively.

Considerable biological activity related to toxicity and hindrance of growth and development of the larvae of C. pipiens has been observed in this study. Of the three plant extracts, $R$. stricta was found to cause higher rate of mortality compared to other plant extracts. Zaitoon ,2001 found that $R$. stricta was very effective against Varroa destructor In the present study, the activity of $R$. stricta extracts has been attributed in part to the saponins and alkaloids in the seeds (El-Shanwani, 1996). C. paradoxa and H. bassifirum exhibited a relatively mild acute effect on mosquito larvae especially in its lower concentrations. However, after 10 days of exposure the toxicity was almost high above $200 \mathrm{ppm}$. The larvicidal activity of some plant extracts, essential oils and phytochemicals against $C$. pipiens have been demonstrated (Traboulsi et al., 2005; Abdelgaleil 2006; Michaelakis et al., 2007; Radwan et al., 2008).

The results obtained in this investigation demonstrate the importance of toxic, growth and development-retarding influence of the extracted plant materials specially $R$. stricta and $C$. paradoxa on $C$. pipiens mosquitoes. Moreover, application of these materials is not likely to leave harmful residues in the environment since they are naturally occurring among the local flora. 
Table 4.Successful pupation and adult emergence of Culex pipiens larvae reared in media containing methanolic plant extracts

\begin{tabular}{|c|c|c|c|}
\hline \multirow[t]{2}{*}{ Plant Extract } & \multirow[t]{2}{*}{ Conc.(ppm) } & \multicolumn{2}{|c|}{ \% successful pupation and adult emergence } \\
\hline & & Pupation & Adult emergence \\
\hline \multirow[t]{6}{*}{ Rhazya stricta } & 100 & 19.3 & 9.0 \\
\hline & 200 & 16.6 & 7.3 \\
\hline & 300 & 9.4 & 5.1 \\
\hline & 400 & 6.1 & 2.2 \\
\hline & 500 & 0.0 & 0.0 \\
\hline & Control & 100.0 & 97.6 \\
\hline \multirow[t]{6}{*}{ Cleome paradoxa } & 100 & 39.3 & 14.9 \\
\hline & 200 & 23.9 & 8.6 \\
\hline & 300 & 15.3 & 5.6 \\
\hline & 400 & 8.6 & 2.2 \\
\hline & 500 & 1.0 & 0.0 \\
\hline & Control & 100 & 100 \\
\hline Heliotrobium & 100 & 68.1 & 39.0 \\
\hline \multirow[t]{5}{*}{ bacciferum } & 200 & 58.3 & 20.2 \\
\hline & 300 & 50.0 & 19.6 \\
\hline & 400 & 31.4 & 10.0 \\
\hline & 500 & 10.0 & 3.9 \\
\hline & Control & 96.6 & 93.2 \\
\hline
\end{tabular}

\section{REFERENCES}

Abbott, W.S. (1925) A method of computing the effectiveness of an insecticide. J. Econ. Entomol., 18, 265-267.

Abdelgaleil, S. A. M. 2006. Chemical composition, insecticidal and fungicidal activities of essential oils isolated from Mentha microphylla and Lantana camara growing in Egypt. Alex. Sci. Exchange J. 27: 18-28.

Bakhashwain, A. A. and A. A. Zaitoun (2009) Effect of some plant extracts on parasitic bee mite, Varroa destructor. $5^{\text {th }}$ Arabic Cong. Of Beekeeping, Abha, Saudi Arabia.

Boussaada, O.; M. K. Ben Halima; S. Ammar; D. Haouas; Z. Mighri and A. N. Helal(2008) insecticidal activity of some Asteraceae plant extracts against Tribolium confusum. ,Bull. Insectology, 61(2), 283-289.

Carlini, CR. and MF Grossidi-de- Sa (2002) Plant toxic proteins with insecticidal properties. A review on their potentialities as insecticides. Toxicon. 40, 1515- 1539.

Chitra, K. C.; R. Janardhan; R. Kameswara and K., Nagaiah (1993). Field evaluation of certain plant products in the control of Brinial Pest complex. Indian Journal of Entomology. 55 (3): 237-240.

Das, N.G.; I. Baruah; P.K. Talukadar and S.C. Das (2003) Evaluation of botanicals as repellents against mosquitoes. J. Vect. Borne Dis. , 40, 49-53

Elhag, E.A.; F.M. Harraz; A.A. Zaitoon and A.K. Salama(1996) Evaluation ofsome wild herb extracts for control of mosquitoes,. J. King Saud Univ., Agric. Sci.,8, 135-1450.
El-shanawani, M. A. (1996) Used plants in Saudi folk medicine. King AbdulAzizfor Science and Technology, Riyadh, Saudi Arabia.

Finney, D.J. (1971) Probit analysis $3^{\text {rd }}$ edition. Cambridge University Press . Cambride, 318 pp.

Jang. Y. S.; M.K. Kim; Y.J. Ahn and H.S. Lee (2002) Larvicidal activity of Brazilian plants against Aedes aegypti and Culex pipiens pallens (Diptera: Culicidae). Agric. Chem. Biotechnol. , 45(3), 131-134.

Kundu, B. R.; R. Ara; M .M. Begum and Z.I. Sarker (2007) Effect of Bishkatali Polygonum hydropiper L. plant extracts against the red flour beetle,Tribolium castaneum Herbst. Univ. J. Zool. Rajshahi Univ. 26, 93-97.

Michaelakis, A.; A. P. Mihou; G. Koliopoulos and E. A. Couladouros 2007. Attract-and-kill strategy. Laboratory studies on hatched larvae of Culex pipiens. Pest Manag. Sci. 63: 954-959.

Migahid, A. M. (1978) Flora of Saudi Arabia. Riyadh University Press, Riyadh, Saudi Arabia.

Radwan, M. A.; S. R. El-Zemity; S. A. Mohamed and S. M. Sherby 2008. Larvicidal activity of some essential oils, monoterpenoids and their corresponding $\mathrm{N}$-methyl carbamate derivatives against Culex pipiens (Diptera: Culicidae) Int. J. Trop. Insect Sci. 28: 61-68.

Rajkumar S. and A. Jebanesan (2005) Oviposition deterent and skin repellent activities of Solanum trilobatum leaf extract against the malarial vector Anopheles stephensi., J. Insect Sci., 5, 1-3. 
Rao D. R. T. R. Mani; R. Rajendran; A. S. Joseph; A. Gjanana and R. Reuben (1995) Development of high level of resistance to Bacillus sphaericus in a field population of Culex quinquefasciatus from Kochi, India. J. Am. Mosq. Control Assoc., 11, 1-5.

Schmutterrer H. (1995) The neem tree Azadirachta indica A. Juss and other meliaceous plants, $\mathrm{VCH}$ publisher, Weinnein, Germany,696.

Severini, C.; R. Rom.; M. Marinucci and M. Rajmond (1993) Mechanisms of insecticide resistance in field populations of Culex pipiencs from Italy. J. Am. Mosq. Control Assoc., 9, 164-186.

Taubes G.(1997) A mosquito bites back. New Yourk Times Magazine. August 24, 126-131.
Traboulsi, A. F.; S. El-Haj; M. Tueni; K. Taoubi; N. Abi Nader and A. Mrad 2005. Repellency and toxicity of aromatic plant extracts against the mosquito Culex pipiens molestus (Diptera: Culicidae). Pest Manag. Sci. 61: 597604.

Venkatachachalam, MR, and J. Jenbanesan (2001) Larvicidal activity of Hydrocotyle javanica Thumb.(Rutacae) extract against Culex quinquefasciatus. J. Ex. Zool., India ,4(1), 99-101.

Zaitoon, A.A. (2001) Evaluation of certain plant extracts for control of parasitic bee mite Varroa jacobsoni. J. Pest. Cont. \& Environ. Sci. 9(3) 77-88 


\section{الملخص العربي}

تأثير ثلاث من المستخلصات النباتية على فقس البيض وتطور اليرقات في بعوضه الكيولكس

$$
\text { أحمد عبد الله باخشوين، أحمد على زيتون }
$$

C. Paradoxa و R. stricta كل التركيزات المستخدمة من

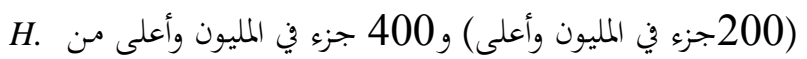

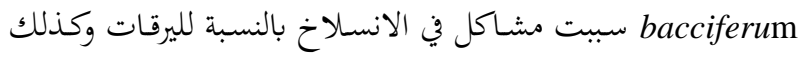


مستخلص R. stricta أكبر خفض في التحول حيث كانت نسب لئ التحول إلى عذراء 19.3\% فقط بينما تحول 9\% إلى حشره كاملة وذلك عندما كان التركيز المستخدم 100جزء في المليون. وقد وجداء

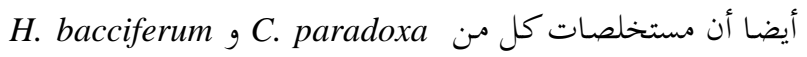

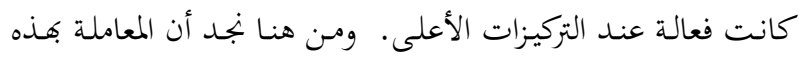
المستخلصات في بيئة نمو اليرقات تعطى نتائج أفضل من استخدام

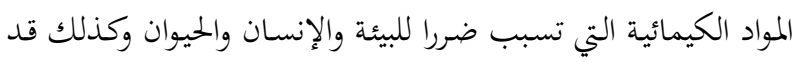
تبدى الحشرات مقاومة لما. تم دراسـة النشـاط الأبادى للمستخلص الميثانولى لكل مـن Heliotrobium ghazya stricta, Cleome paradoxa وذلك ضـــ يرقـات وتطـور بعوضـة الكيـوليكس. bacciferum

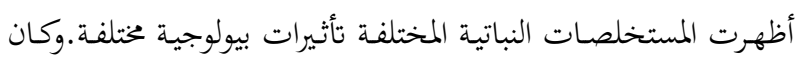
الأكثر تأثيرا هو مستخلص نبات Rhazya stricta والذي أظهر فعل

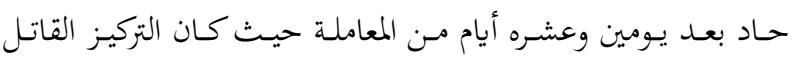
50\% مـن العشيرة 154.2 و 84.2 جزء في المليون على التوالي.


stricta فقس البيض بصوره كبيره في المعاملات الخاصة ب R. Stricta . 